\title{
Isolasi dan Identifikasi Streptomycetes dari Rizosfer Jagung (Zea mays L.) yang Berpotensi sebagai Penghasil Antibiotika
}

\section{Isolation and Identification of Streptomycetes from Rhizosphere of Corn (Zea mays L.) that is Potential to be Antibiotic Producer}

\author{
Ambarwati $^{1 *}$, C. J. Soegihardjo ${ }^{2}$, dan Langkah Sembiring ${ }^{3}$ \\ ${ }^{1}$ Prodi Kesehatan Masyarakat Fakultas Ilmu Kesehatan Universitas Muhammadiyah Surakarta \\ Jl. A. Yani Tromol Pos I, Pabelan Surakarta \\ ${ }^{2}$ Fakultas Farmasi Universitas Gadjah Mada Yogyakarta \\ ${ }^{3}$ Fakultas Biologi Universitas Gadjah Mada Yogyakarta \\ E-mail:ambarwati7@yahoo.com *Penulis untuk korespondensi
}

\begin{abstract}
In attempt to understand the diversity of Actinomycetes that is potential to be antibiotic producer, Streptomycetes were isolated and identified from soil sample taken from rhizosphere and non-rhizosphere of corn (Zea mays L.). The best antibiotic producers were identified by Scanning Electron Microscopy analysis and the identification of antibiotic produced conducted by using Thin Layer Chromatography analysis. The result of the study showed that 58 isolates were assigned to 17 colour groups. Ten isolates among the representatives of 17 colour groups were found potential to be antibiotic producer. Four isolates out of 10 isolates could inhibit both Staphylococcus aureus ATCC 25923 and Bacilus subtilis FNCC 0060, one isolate could inhibit only Staphylococcus aureus ATCC 25923 and five isolates could inhibit only Bacilus subtilis FNCC 0060. But no isolate could inhibit Escherichia coli ATCC 35218 and Salmonella typhimurium FNCC 0164. Among 10 isolates of antibiotic producer it was found that only one isolate (RNJ14) could strongly inhibit Staphylococcus aureus ATCC 25923 with inhibition zone diameter of $32.33 \mathrm{~mm}$. On the bases of Thin Layer Chromatography analysis, the antibiotic produced by the isolate RNJ14 was identified to be lincomycin. Therefore it could be concluded that streptomycetes isolated from the rhizosphere and non-rhizosphere of corn (Zea mays L.) were potential to produce antibiotic.
\end{abstract}

Key words: Streptomycetes, rhizosphere, corn, antibiotic

\begin{abstract}
Abstrak
Dalam upaya mengetahui keanekaragaman anggota genus Actinomycetes yang berpotensi menghasilkan antibiotika, Streptomisetes diisolasi dari sampel tanah non-rizosfer tanaman jagung (Zea mays L.). Identifikasi terhadap isolat yang unggul dilakukan berdasarkan karakterisasi dengan menggunakan Mikroskop Elektron (SEM) dan diidentifikasi antibiotika yang dihasilkan dilakukan dengan metode Kromatografi Lapis Tipis (KLT). Berdasarkan hasil penelitian diperoleh sebanyak 58 isolat yang dikelompokkan menjadi 17 colour groups. Sepuluh isolat yang mewakili 17 colour groups diketahui berpotensi menghasilkan antibiotika. Empat isolat dari 10 isolat dapat menghambat pertumbuhan baik Staphylococcus aureus ATCC 25923 maupun Bacilus subtilis FNCC 0060, satu isolat hanya dapat menghambat Staphylococcus aureus ATCC 25923 dan lima isolat hanya dapat menghambat Bacilus subtilis FNCC 0060. Namun, tidak ada isolat yang dapat menghambat Escherichia coli ATCC 35218 dan Salmonella typhimurium FNCC 0164. Dari 10 isolat yang berpotensi menghasilkan antibiotika, diketahui hanya satu isolat (RNJ14) yang dapat menghambat Staphylococcus aureus ATCC 25923 dengan kuat dengan diameter daerah hambatan $32,33 \mathrm{~mm}$. Berdasarkan hasil analisis dengan metode Kromatografi Lapis Tipis, antibiotika yang dihasilkan oleh isolat RNJ14 adalah linkomisin. Dengan demikian dapat disimpulkan bahwa Streptomysetes yang diisolasi dari rizosfer dan non-rizosfer tanaman jagung (Zea mays L.) berpotensi menghasilkan antibiotik.
\end{abstract}

Kata kunci: Streptomisetes, rizosfer, tanaman jagung, antibiotika 


\section{Pendahuluan}

Penemuan antibiotik penisilin yang dihasilkan oleh kapang Penicillium notatum oleh Alexander Fleming pada tahun 1929, telah mendorong penelitian untuk menemukan antibiotik baru dari bakteri (Suarsana et al., 2001), fungi (Prihatiningtias et al., 2005) dan Actinomycetes (Oskay et al., 2004; Nedialkova dan Naidenova, 2005; Lestari, 2006). Saat ini banyak penelitian yang difokuskan pada kelas Actinomycetes terutama anggota genus Streptomyces yang terbukti berpotensi besar sebagai penghasil antibiotik.

Streptomyces dicirikan oleh: koloninya kering dan kecil dengan diameter 1-10 mm. Pada medium khusus dapat menghasilkan berbagai warna yang berbeda baik pada miselium vegetatif maupun miselium udara (Holt et al., 1994). Miselium udara bila dewasa akan membentuk rantai spora yang terdiri dari 3 sampai 50 spora atau lebih (Holt et al., 1994; Prescott et al., 1999). Morfologi rantai spora bisa digolongkan lurus, lentur atau spiral, sedangkan ornamen permukaan spora bisa dibedakan menjadi halus, berkutil, berduri atau berbulu (Korn-Wendisch dan Kutzner, 1992). Banyak strain yang menghasilkan antibiotik (Holt et al., 1994; Madigan et al., 2003). Gram positif tetapi tidak tahan asam, tumbuh optimal pada suhu $25-35^{\circ} \mathrm{C}$, dan $\mathrm{pH}$ optimal $6,5-8,0$ (Holt et al., 1994).

Berdasarkan data dari Antibiotic Literature Database Italia, di antara 8000 antibiotika, 45,6\% dihasilkan oleh anggota genus Streptomyces dan hanya $21,5 \%$ yang dihasilkan oleh jamur, $16,9 \%$ dari bakteri, dan $16 \%$ dari anggota Actinomycetes lain (Lazzarini et al., 2000). Menurut Mutschler (1991), banyak antibiotik yang dihasilkan oleh anggota genus Streptomyces, yaitu streptomisin (S. griseus), aureomisin (S. aureofaciens), oleandomisin $(S$. antibioticus), spiramisin (S. ambofaciens), dan eritromisin (S. erythreus), yang masing-masing mempunyai khasiat yang berlainan.

Mikroorganisme, termasuk anggota genus Streptomyces dapat ditemukan di tanah maupun di daerah rizosfer. Pada umumnya populasi mikroorganisme pada rizosfer jauh lebih tinggi dibandingkan dengan populasi pada bagian tanah lainnya. Hal ini disebabkan tanaman mempunyai kemampuan mengeluarkan eksudat yang berguna sebagai sumber energi bagi kehidupan mikroorganisme yang ada di sekitar perakaran tersebut (Bais et al., 2006).

Beberapa penelitian telah berhasil mengisolasi Actinomycetes dari tanah yang berpotensi sebagai penghasil antibiotik (Oskay et al., 2004; Nedialkova dan Naidenova, 2005; Lestari, 2006). Berdasarkan hasil penelitian de Araujol et al., (2000) ditemukan anggota genus Streptomyces endofit pada akar dan daun jagung yang berperan sebagai antibakteri dan antifungi. Selain itu, akar dan eksudat akar jagung juga berperan menghambat fungi patogen pada tanaman, yaitu Fusarium oxysporum dan Cephalosporium gregatum (Park et al., 2004). Pada penelitian ini sampel diambil dari rizosfer jagung (Zea mays L.). Hal ini didasarkan pada pemikiran bahwa rizosfer merupakan salah satu habitat Actinomycetes, sehingga dimungkinkan pada rizosfer jagung ditemukan anggota genus Streptomyces. Tujuan penelitian ini adalah untuk mengetahui keanekaragaman anggota genus Streptomyces yang ditemukan pada rizosfer jagung (Zea mays L.) yang berpotensi sebagai penghasil antibiotik.

\section{Metode Penelitian}

\section{Sampel Tanah}

Sampel tanah diambil dari lima lokasi rizosfer dan non-rizosfer tanaman jagung hibrida merk P-11 umur 55 hari yang ditanam di sawah Sicangkring, Kiringan, Tulung, Klaten.

\section{Isolasi dan Purifikasi Streptomycetes}

Dilakukan pengenceran sampel tanah dari tingkat $10^{-1}$ sampai $10^{-5}$, dengan cara diambil sebanyak satu gram sampel tanah dan ditambahkan pada $9 \mathrm{ml}$ larutan ringer 1/4 strength (ini merupakan pengenceran tingkat $10^{-1}$ ). Dari pengenceran tingkat $10^{-1}$ diambil satu $\mathrm{ml}$ dan ditambahkan pada $9 \mathrm{ml}$ larutan ringer 1/4 strength (ini merupakan pengenceran tingkat $10^{-2}$ ). Dengan cara yang sama dilakukan pengenceran tingkat $10^{-3}, 10^{-4}$ dan $10^{-5}$. Dari masing-masing tingkat pengenceran $\left(10^{-1}\right.$ sampai $10^{-5}$ ) diambil $0,1 \mathrm{ml}$ dan diinokulasikan secara surface plate pada media Starch-Casein 
Agar dan media Raffinosa-Histidin Agar. Media yang telah diinokulasi diinkubasikan pada suhu $25^{\circ} \mathrm{C}$ selama empat hari sampai dua minggu (Sembiring et al., 2000). Dari koloni yang menunjukkan kenampakan berbeda dipurifikasi pada media Kenkninght and Munaier Agar.

\section{Pengelompokan Warna dan Pewarnaan Gram}

Dari hasil purifikasi dilakukan colour grouping pada media Oatmeal Agar (Sembiring et al., 2000). Hal ini dilakukan untuk mengelompokkan isolat berdasarkan warna aerial miselium, vegetatif miselium dan mengetahui warna pigmen yang dihasilkan terdifusikan pada media atau tidak. Pewarnaan Gram dilakukan berdasarkan prosedur Prescott et al., (1999).

\section{Uji Potensi Isolat sebagai Penghasil Antibiotik}

Isolat-isolat hasil purifikasi diuji kemampuannya sebagai penghasil antibiotik dengan cara, isolat tersebut diuji daya hambatnya terhadap bakteri uji (E. coli ATCC 35218, S. typhimurium FNCC 0164, S. aureus ATCC 25923, dan B. subtilis FNCC 0060), menggunakan metode agar blok. Dibuat kultur agar cawan dari bakteri uji (diambil satu tetes suspensi dari tiap-tiap bakteri uji, ditambahkan media Nutrient Agar cair (Oxoid), diratakan dan dipadatkan. Selanjutnya cawan petri dibagi menjadi tiga kuadran. Setelah itu agar cawan dilubangi dengan cork borer berdiameter 8 $\mathrm{mm}$. Dengan cara yang sama dibuat agar blok biakan isolat anggota genus Streptomyces. Agar blok yang terbentuk ditempatkan pada lubang agar cawan pada salah satu kuadran. Langkah yang sama dilakukan pada 2 kuadran lainnya, ini dilakukan terhadap semua koloni. Langkah selanjutnya, semua biakan diinkubasikan pada suhu $30^{\circ} \mathrm{C}$ selama empat hari (Nedialkova dan Naidenova, 2005).

\section{Identifikasi Isolat Terpilih dengan SEM}

Dari hasil uji potensi isolat sebagai penghasil antibiotik, didapatkan isolat terpilih, yaitu isolat yang menunjukkan diameter daerah hambatan $25 \mathrm{~mm}$ atau lebih. Selanjutnya, isolat-isolat terpilih tersebut diidentifikasi berdasarkan morfologi rantai spora dan ornamen permukaan spora menggunakan SEM (Scanning Electron Microscopy), di Unit
Mikroskop Elektron Universitas Airlangga Surabaya.

Identifikasi Senyawa yang Diduga Antibiotik

Identifikasi senyawa yang diduga sebagai antibiotik dilakukan dengan Kromatografi Lapis Tipis (KLT). Fase diam digunakan lempeng silica gel $\mathrm{GF}_{254}$, sedangkan fase gerak digunakan methanol : kloroform $=9: 1$ (Isnaeni, 2005). Pengamatan spot dilakukan dengan sinar UV pada panjang gelombang 254 $\mathrm{nm}$. Nilai Rf sampel dibandingkan dengan nilai $\mathrm{Rf}$ antibiotik pembanding (tetrasiklin, linkomisin, eritromisin, kanamisin dan kloramfenikol) untuk memperkirakan antibiotik yang dihasilkan oleh isolat terpilih.

\section{Hasil dan Pembahasan}

\section{Isolasi dan Purifikasi}

Berdasarkan hasil isolasi diketahui densitas anggota genus Streptomyces pada rizosfer jagung sebanyak $21,58 \times 10^{4} \mathrm{Cfu} / \mathrm{g}$-dw, sedangkan pada non rhizosfer jagung sebanyak $16,60 \times 10^{4} \mathrm{Cfu} / \mathrm{g}-\mathrm{dw}$. Dengan demikian densitas anggota genus Streptomyces per gram sampel tanah pada rizosfer lebih banyak dari pada densitas anggota genus Streptomyces pada sampel non-rizosfer. Hal ini disebabkan akar tanaman mempunyai kemampuan mengeluarkan eksudat (Rao, 2001). Eksudat mengandung berbagai macam asam amino (Bolton et al., 1992), gula, asam organik, vitamin-vitamin, nukleotida dan senyawa lainnya (Rao, 2001), fenolik, musigel (polisakarida) dan protein (Bais et al., 2006) yang berguna sebagai sumber energi bagi kehidupan mikroorganisme yang ada di sekitar perakaran tersebut. Dari hasil isolasi tersebut dilakukan purifikasi dan didapatkan sebanyak 58 isolat dengan perincian 23 isolat dari rizosfer jagung dan 35 isolat dari non-rizosfer jagung. Banyaknya isolat tersebut menunjukkan keanekaragaman anggota genus Streptomyces yang ditemukan.

\section{Colour Grouping}

Hasil colour grouping disajikan pada Tabel 1, sedangkan foto hasil colour grouping disajikan pada Gambar 1. 
Colour grouping merupakan salah satu cara yang dapat ditempuh untuk mengidentifikasi suatu isolat termasuk Streptomyces atau tidak, karena anggota genus Streptomyces mempunyai ciri menghasilkan warna pada media Oatmeal agar. Colour grouping dilakukan untuk menggolongkan isolat berdasarkan warna miselium aerial, miselium vegetatif dan mengetahui apakah warna pigmen yang dihasilkan terdifusikan pada media atau tidak. Isolat yang memiliki warna aerial miselium sama, vegetatif miselium sama dan warna pigmennya terdifusi maka akan digolongkan dalam satu isolat, sebaliknya meskipun suatu isolat mempunyai warna aerial miselium yang sama, vegetatif miselium yang sama pula tetapi yang satu warna pigmennya terdifusi yang satunya tidak, maka tidak dapat digolongkan dalam satu isolat. Berdasarkan uji Colour grouping diketahui bahwa isolat yang ditemukan termasuk anggota genus Streptomyces.

\section{Pewarnaan Gram}

Foto hasil pewarnaan Gram isolat terpilih disajikan pada Gambar 1.

Pewarnaan Gram dilakukan untuk menggolongkan bakteri dalam dua kelompok, yaitu Gram positif dan Gram negatif. Anggota genus Streptomyces mempunyai ciri bentuk batang bercabang, warna ungu dan Gram positif. Berdasarkan hasil uji pewarnaan Gram diketahui bahwa isolat yang ditemukan termasuk anggota Genus Streptomyces.

Tabel 1. Hasil Colour grouping anggota genus Streptomyces dari rizosfer dan non-rizosfer jagung (Zea mays L.).

\begin{tabular}{|c|c|c|c|c|c|}
\hline$\overline{\text { Group }}$ & $\begin{array}{c}\text { Warna Miselium } \\
\text { Udara }\end{array}$ & $\begin{array}{c}\text { Warna Miselium } \\
\text { Vegetatif }\end{array}$ & \multicolumn{2}{|c|}{ Warna Pigmen yang Jumlah } & Anggota Representatif \\
\hline \multicolumn{6}{|c|}{ Rizosfer Jagung } \\
\hline GJ1 & Abu-abu kecoklatan & Coklat muda & - & 4 & SJ1, SJ4, RJ6, RJ9 \\
\hline GJ2 & Merah muda keputihan & Coklat muda & - & 3 & $\mathrm{SJ} 2, \mathrm{SJ} 3, \mathrm{RJ} 8$ \\
\hline GJ3 & Abu-abu kehitaman & Hijau lumut & Kuning & 5 & SJ5, RJ7, RJ10, RJ14, RJ19 \\
\hline GJ4 & Coklat muda & Coklat muda & - & 3 & SJ5, RJ12, RJ16 \\
\hline GJ5 & Orange keputihan & Coklat muda & - & 5 & RJ11, RJ15, RJ17, SJ21, RJ23 \\
\hline GJ6 & Hijau & Coklat tua & Coklat & 3 & RJ13, RJ18, RJ20 \\
\hline \multicolumn{6}{|c|}{ Non-Rizosfer Jagung } \\
\hline GNJ1 & Abu-abu keputihan & Kuning & - & 3 & SNJ3, SNJ4, SNJ16 \\
\hline GNJ2 & Orange keputihan & Coklat muda & - & 4 & SNJ1, SNJ2, SNJ5, RNJ24, \\
\hline GNJ3 & Merah muda keputihan & Coklat muda & - & 3 & SNJ6, SNJ8, SNJ12 \\
\hline GNJ4 & Putih merah muda & Kuning kecoklatan & Coklat tua & 3 & SNJ9, SNJ11, SNJ13 \\
\hline GNJ5 & Putih Merah bata & Orange kecoklatan & Coklat & 3 & SNJ7, SNJ10, RNJ14 \\
\hline GNJ6 & Abu-abu kehijauan & Coklat & Coklat muda & 4 & SNJ15, RNJ18, RNJ29, RNJ35 \\
\hline GNJ7 & Abu-abu keputihan & Coklat & Coklat muda & 3 & SNJ17, RNJ20, RNJ23 \\
\hline GNJ8 & Abu-abu kehitaman & Hijau lumut & Kuning & 3 & RNJ19, RNJ21, RNJ34 \\
\hline GNJ9 & Abu-abu kehijauan & Hitam & Coklat & 2 & RNJ22, RNJ27 \\
\hline GNJ10 & Abu-abu & Kuning kecoklatan & Kuning & 3 & RNJ25, RNJ28, SNJ32 \\
\hline GNJ11 & Abu-abu keputihan & Kuning muda & - & 4 & RNJ26, RNJ30, SNJ31, SNJ33 \\
\hline \multicolumn{3}{|c|}{ Total Isolat } & \multicolumn{3}{|c|}{58} \\
\hline
\end{tabular}

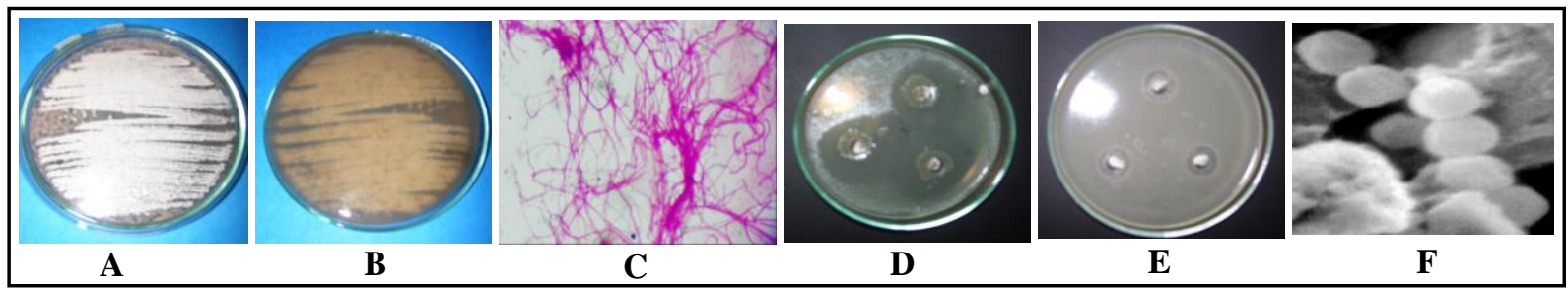

Gambar 1. A. Hasil colour grouping isolat RNJ14 (tampak atas), B. Hasil colour grouping isolat RNJ14 (tampak bawah), C. Hasil pewarnaan gram isolat RNJ14, D. Hasil uji hambatan isolat RNJ14 pada S. aureus ATCC 25923, E. Hasil uji hambatan isolat RNJ14 pada B. subtilis FNCC 0060, F. Hasil SEM isolat RNJ14. 


\section{Uji Potensi Isolat sebagai Penghasil Antibiotika}

Hasil uji potensi isolat sebagai penghasil antibiotika disajikan pada Tabel 2, sedangkan foto hasil uji potensi isolat terpilih sebagai penghasil antibiotika disajikan pada Gambar 1 .

Uji potensi isolat sebagai penghasil antibiotika dilakukan untuk mengetahui kemampuan isolat yang ditemukan sebagai penghasil antibiotika. Uji dilakukan dengan metode agar blok pada empat bakteri uji, yaitu $E$. coli dan $S$. typhimurium sebagai wakil bakteri Gram negatif serta $S$. aureus dan $B$. subtilis sebagai wakil bakteri Gram positif. Adanya potensi isolat sebagai penghasil antibiotik ditunjukkan dengan adanya daerah hambatan yang terbentuk di sekitar bakteri uji.

\section{Identifikasi Isolat Terpilih dengan SEM}

Foto hasil SEM isolat terpilih disajikan pada Gambar 1.

Pengamatan dengan SEM (Scanning Electron Microscopy) untuk mengidentifikasi apakah isolat yang ditemukan betul-betul merupakan anggota genus Streptomyces. Ciri anggota genus Streptomyces dapat diketahui dari jumlah spora dan morfologi serta ornamen permukaan rantai spora. Berdasarkan hasil SEM diketahui bahwa isolat unggul yang ditemukan termasuk anggota genus Streptomyces.

\section{Identifikasi Senyawa yang Diduga Antibiotika}

Hasil KLT dari isolat terpilih dan antibiotik pembanding disajikan pada Tabel 3.

Dengan Kromatografi Lapis Tipis (KLT) dapat diperkirakan jenis antibiotika yang dihasilkan oleh isolat unggul, sehingga dapat diketahui apakah antibiotika yang dihasilkan tergolong antibiotik baru (belum pernah ada) ataukah antibiotika lama (sudah pernah ada). Hal ini dapat diketahui dengan membandingkan antibiotika yang dihasilkan oleh isolat unggul dengan antibiotika pembanding. Jika antibiotika yang dihasilkan oleh isolat unggul tidak sama dengan semua antibiotika pembanding, dimungkinkan antibiotika tersebut berpotensi menjadi antibiotika baru.
Dari penelitian ini ditemukan sebanyak 58 isolat dengan perincian 23 isolat dari rizosfer jagung dan 35 isolat dari non-rizosfer jagung. Berdasarkan hasil pengamatan morfologi koloni, colour grouping dan pengecatan Gram, semua isolat yang diperoleh diduga sebagai anggota genus Streptomyces. Di antara 23 isolat dari rizosfer jagung dapat dikelompokkan menjadi enam colour groups beranggota banyak isolat. Adapun di antara 35 isolat dari non-rizosfer jagung dapat dikelompokkan menjadi 11 colour groups beranggota banyak isolat. Sepuluh isolat di antara 17 colour groups diketahui berpotensi sebagai penghasil antibiotika. Empat isolat dari 10 isolat tersebut mampu menghambat baik Staphylococcus aureus ATCC 25923 maupun Bacilus subtilis FNCC 0060, satu isolat hanya mampu menghambat Staphylococcus aureus ATCC 25923 dan lima isolat hanya mampu menghambat Bacilus subtilis FNCC 0060. Namun di antara sepuluh isolat tersebut tidak satu pun isolat yang mampu menghambat Escherichia coli ATCC 35218 maupun Salmonella typhimurium FNCC 0164 (bakteri Gram negatif).

Menurut Nedialkova dan Naidenova (2005), bila diameter daerah hambatan (tidak termasuk diameter agar blok $8 \mathrm{~mm}$ ) sebesar 7-15 mm, aktivitas penghambatannya dikategorikan lemah, 16-25 mm dikategorikan sedang, dan lebih dari $25 \mathrm{~mm}$ dikategorikan kuat. Berdasarkan ketentuan tersebut maka di antara 10 isolat yang berpotensi sebagai penghasil antibiotika, diketahui hanya satu isolat yaitu RNJ14 yang mampu menghambat Staphylococcus aureus ATCC 25923 dengan kuat dengan diameter daerah hambatan sebesar $32,33 \mathrm{~mm}$. Berdasarkan morfologi rantai spora dan ornamen permukaan spora, isolat RNJ14 diduga sebagai Streptomyces sp. Berdasarkan hasil uji KLT, isolat RNJ14 memiliki nilai Rf sebesar 0,68, di mana nilai Rf ini sama dengan Rf linkomisin, selain itu warna pemendaran isolat RNJ14 di bawah sinar $\mathrm{UV}_{254} \mathrm{~nm}$ sama dengan warna pemendaran antibiotik linkomisin, dengan demikian metabolit sekunder yang dihasilkan oleh isolat RNJ14 dapat diduga sebagai antibiotik linkomisin. Cara kerja antibiotik ini dengan mengganggu sintesis protein (Mutschler, 1991; Suwandi, 1992). 
Deskripsi dari isolat RNJ14: ditemukan dari sampel tanah non-rizosfer jagung (Zea mays L.), yang diisolasi pada media RaffinoseHistidine Agar, warna koloni putih merah muda (tampak atas) dan orange keputihan (tampak bawah), warna miselium udara putih merah bata, miselium vegetatif oranye kecoklatan, warna terdifusi coklat, bentuk batang bercabang warna ungu, Gram positif, spora bentuk bulat, jumlah rantai spora lebih dari 3, dan ornamen permukaan spora halus.

Tabel 2. Hasil uji potensi isolat sebagai penghasil antibiotik.

\begin{tabular}{|c|c|c|c|c|c|c|}
\hline \multirow[t]{2}{*}{ No. } & \multirow[t]{2}{*}{ Group } & \multirow[t]{2}{*}{ Kode Isolat } & \multicolumn{4}{|c|}{$\begin{array}{c}\text { Diameter Daerah Hambatan (mm) yang Dihasilkan oleh Isolat terhadap } \\
\text { Bakteri Uji }\end{array}$} \\
\hline & & & $\begin{array}{c}E . \text { coli } \\
\text { ATCC } 35218\end{array}$ & $\begin{array}{l}\text { S. typhimurium } \\
\text { FNCC } 0164\end{array}$ & $\begin{array}{c}\text { S. aureus } \\
\text { ATCC } 25923\end{array}$ & $\begin{array}{l}\text { B. subtilis FNCC } \\
\quad 0060\end{array}$ \\
\hline 1. & GJ1 & RJ6 & 0,00 & "0,00 & 0,00 & $10,33^{*}$ \\
\hline 2. & GJ2 & RJ8 & 0,00 & 0,00 & $15,67 * *$ & $9,00^{*}$ \\
\hline 3. & GJ3 & RJ10 & 0,00 & 0,00 & 0,00 & $11,67 *$ \\
\hline 4. & GJ4 & RJ16 & 0,00 & 0,00 & 0,00 & $12,67 *$ \\
\hline 5. & GJ5 & RJ23 & 0,00 & 0,00 & 0,00 & $12,33^{*}$ \\
\hline 6. & GJ6 & RJ20 & 0,00 & 0,00 & $13,33^{*}$ & $12,33^{*}$ \\
\hline 7. & GNJ3 & SNJ6 & 0,00 & 0,00 & 0,00 & $12,33^{*}$ \\
\hline 8. & GNJ4 & SNJ13 & 0,00 & 0,00 & $13,33^{*}$ & $11,33^{*}$ \\
\hline 9. & GNJ5 & RNJ14 & 0,00 & 0,00 & $32,33 * * *$ & $11,67 *$ \\
\hline 10. & GNJ9 & RNJ22 & 0,00 & 0,00 & $10,00^{*}$ & 0,00 \\
\hline
\end{tabular}

Keterangan : Potensi isolat sebagai penghasil antibiotik, diameter daerah hambatan tidak termasuk diameter agar blok $8 \mathrm{~mm}$ (Nedialkova dan Naidenova, 2005).

* = daerah hambatan yang terbentuk tergolong lemah $(7-15 \mathrm{~mm})$

** = daerah hambatan yang terbentuk tergolong sedang $(16-25 \mathrm{~mm})$

$* * *$ = daerah hambatan yang terbentuk tergolong kuat (lebih dari $25 \mathrm{~mm}$ )

Tabel 3. Hasil pengukuran Rf isolat RNJ14 dan antibiotik pembanding.

\begin{tabular}{clcc}
\hline \hline No. & Kode Isolat/Antibiotik & Rf & Deteksi Sinar UV $\mathbf{~ V 5}_{\mathbf{2 5}} \mathbf{~ n m}$ \\
\hline \hline 1. & RNJ14 & 0,68 & Biru tua \\
2. & Tetrasiklin & 0,28 & Coklat tua \\
3. & Linkomisin & 0,68 & Biru tua \\
4. & Eritromisin & 0,36 & Biru tua \\
5. & Kanamisin & 0,44 & Coklat tua \\
6. & Kloramfenikol & 0,82 & Biru tua \\
\hline \hline
\end{tabular}

\section{Simpulan dan Saran}

\section{Simpulan}

Berdasarkan hasil penelitian disimpulkan: ditemukan 58 isolat Streptomycetes, dengan perincian 23 isolat dari rizosfer jagung dan 35 isolat dari non-rizosfer jagung. Sebanyak 10 isolat berpotensi sebagai penghasil antibiotika dengan spektrum kerja menghambat bakteri Gram positif. Satu isolat (RNJ14) mampu menghambat Staphylococcus aureus ATCC 25923 dengan kuat dengan diameter daerah hambatan sebesar $32,33 \mathrm{~mm}$. Isolat RNJ14 diduga menghasilkan antibiotik linkomisin.

\section{Saran}

Mengingat ada satu isolat (RNJ14) yang berpotensi sebagai penghasil antibiotika dengan hambatan yang kuat terhadap bakteri Gram positif, perlu dilakukan penelitian lebih lanjut untuk memurnikan senyawa metabolit sekunder yang dihasilkan oleh isolat tersebut dan perlu identifikasi isolat secara molekuler untuk identifikasi sampai tingkat spesies. Selain itu perlu dilakukan elusidasi struktur dari antibiotika yang dihasilkan oleh isolat unggul dengan analisis Carbon - Hidrogen $(\mathrm{CH})$ dan spektroskopi. 


\section{Ucapan Terima Kasih}

Penulis mengucapkan terima kasih kepada: Dikti, yang telah membiayai penelitian ini dengan Beasiswa Program Pascasarjana (BPPS). Prof. Sukarti Moeljoprawiro, M.App.Sc., PhD, yang memberikan bimbingan, masukan, saran, dorongan, dan semangat kepada penulis untuk perbaikan penelitian ini dan Ibu Dian Widyastuti, SE. yang mendoakan dan membantu penulis di laboratorium dari awal penelitian sampai selesai.

\section{Daftar Pustaka}

Bais, H.P., Weir, T.L., Perry, L.G., Gilroy, S. dan Vivanco, J.M. 2006. The Role of Exudates in Rizosfer Interactions with Plants and Other Organisms. The Annual Review of Plant Biology, 57: 233-266.

Bolton, H.Jr., Fredrickson, J.K. dan Elliott, L.F. 1992. Microbial Ecology of The Rizosfer. In Soil Microbial Ecology. (F.B. Metting, Jr, Ed). Marcel Dekker, Inc. New York.

de Araújo1, J.M., da Silva, A.C. dan Azevedo, J.L. 2000. Isolation of Endophytic Actinomycetes from Roots and Leaves of Maize (Zea mays L.) Brazilian Archives of Biology and Technology, 43 (4): 52-58.

Holt, J.G., Krieg, N.R., Sneath, P.H.A., Staley, J.T. dan Williams, S.T. 1994. Bergey's Manual of Determinative Bacteriology. Ninth Edition. Lippincott Williams \& Wilkins. USA.

Isnaeni. 2005. Bioautografi Antibiotika Hasil Fermentasi Mutan Streptomyces griseus ATCC 10137. Majalah Farmasi Airlangga, 5 (1): 16-19.

Korn-Wendisch, F. dan Kutzner, H.J. 1992. The Family Streptomycetaceae. The Prokaryotes, Second Edition. In: Balows, A., Truper, H.G., Dworkin, M., Harder, W. and Karl-Heinz, S. (Eds.). A Handbook on the Biology of Bacteria: Ecophysiology, Isolation, Identification, Aplications. Springer-Verlag, New york, Berlin, Heidelberg, London, Paris, Tokyo, Hong Kong, Barcelona, and Budapest.

Lazzarini, A., Cavaletti, L., Toppo, G. dan Marinelli, F. 2000. Rare Genera of Actinomycetes as Potential Producer of New Antibiotics. Antonie van Leeuwenhoek, 78 (3-4): 399-405.
Lestari, Y. 2006. Identification of Indegenous Streptomyces spp. Producing Antibacterial Compounds. J. Mikrobiologi Indonesia, 11 (2): 99-101.

Madigan, M.T., Martinko, J.M. dan Parker, J. 2003. Brock Biology of Microorganisms. Tent Edition. Prentice Hall, USA.

Mutschler, E. 1991. Dinamika Obat, Buku Ajar Farmakologi dan Toksikologi. Edisi Kelima. Alih Bahasa Widianto, M.B. dan Ranti, A.S. Penerbit ITB, Bandung.

Nedialkova, D. dan Naidenova, M. 2005. Screening the Antimicrobial Activity of Actinomycetes Strains Isolated from Antarctica. J. of Culture Collections, 4 (1): 29-35.

Oskay, M., Tamer, A.U. dan Azeri, C. 2004. Antibacterial Activity of some Actinomycetes Isolated from Farming Soil of Turkey. African J. of Biotechnology, 3 (9): 441-446.

Park, S., Takano, Y., Matsuura, H. dan Yoshihara, T. 2004. Antifungal Compounds from The Root and Root Exudate of Zea mays. Bioscience, Biotech. Biochem, 68 (6): 1366-1368.

Prescott, L.M., Harley, J.P. dan Klein, D.A. 1999. Microbiology. Fourth Edition. WCB McGraw-Hill, Boston.

Prihatiningtias, W., Widyastuti, S.M. dan Wahyuono, S. 2005. Senyawa Antibakteri dari Thievalia polygonoperda Fungi Endofit Tumbuhan Akar Kuning (Fibraurea chloroleuca. Miers). J. Farmasi Indonesia Pharmacon, 6 (1): 19-22.

Rao, N.S.S. 2001. Soil Microbiology. Soil Microorganism and Plant Growth. Fourth Edition. Science Publishers, Inc. Enfield (NH), USA.

Sembiring, L., Ward, A.C. dan Goodfellow, M. 2000. Selective Isolation and Characterisation of Members of the Streptomyces violaceusniger Clade Associated with the Roots of Paraserianthes falcataria. Antonie van Leeuwenhoek, 78 (3-4): 353-366.

Suarsana, I.N., Utama, I.H. dan Suartini, N.G.A.A. 2001. Aktivitas In vitro Senyawa Antimikroba dari Streptococcus lactis. J. Veteriner, 2 (1)

Suwandi, U. 1992. Mekanisme Kerja Antibiotik. Cermin Dunia Kedokteran, 76 (59): 56-59. 